\title{
Mnichovská dohoda z roku 1619
}

\author{
Václav Valeš
}

Fakulta právnická, Západočeská univerzita v Plzni

Kontaktníe-mail:vales.vaclav@seznam.cz

\section{The Treaty of Munich of 1619}

\begin{abstract}
:
This article describes the origin, content and consequences of the treaty of Munich of 8th October 1619. This treaty was concluded between Holy Roman Emperor Ferdinand II and the Bavarian Duke Maximilian I. Under this agreement, Bavaria helped reactivate the Catholic League, which provided assistance to the Habsburg dynasty for the liquidation of the Bohemian revolt (1618-1620). Bavaria obtained the Palatinate linked to the Electoral title under this agreement as a compensation.
\end{abstract}

\section{Keywords:}

Holy Roman Empire of the German Nation; Bavaria; Palatinate; Catholic League; Ferdinand II (1619-1637); Maximilian I (1597/1598-1651); Electors; Bohemian Revolt (1618-1620)

\section{Klíčová slova:}

Svatá říše římská národa německého; Bavorsko; Falc; Katolická liga; Ferdinand II. (1619-1637); Maxmilián I. (1597/1598-1651); kurfiřti; české stavovské povstání (1618-1620)

DOI: $10.14712 / 2464689 X .2019 .4$

\section{Úvod}

Pokud se v českém prostředí použije termín „mnichovská dohoda“, bez dalšího připadne čtenáři či posluchači zcela automaticky na mysl osudný dokument podepsaný „o nás bez nás“ v bavorském hlavním městě v noci z 29. na 30. září 1938 zástupci Německa, Itálie, Francie a Spojeného království, který zlikvidoval první Československou republiku a na následujících sedm let vydal český národ na milost a nemilost Hitlerovi. Existuje 
však také mezinárodní smlouva téhož jména, která byla sjednána dne 8 . ř́ijna 1619 mezi ř́msko-německým císařem Ferdinandem II. (1619-1637) a bavorským vévodou Maxmiliánem I. (1597/1598-1651), jež ovlivnila tok českých dějin nikoli na necelých sedm let jako diktát velmocí z roku 1938, ale téměř na tři století. Zatímco v češtině se označení těchto dvou právních památek prŕíliš neliší, v němčině ano (Münchner Abkommen 1938, Münchner Vertrag 1619). Následující pojednání je věnováno příčinám vzniku, analýze obsahu a důsledkům důležité, přesto však opomíjené nebo jen několika slovy zmiňované mnichovské dohody z roku 1619.

\section{Diplomatická předehra}

Když dne 23. května 1618 třetí pražská defenestrace odstartovala válku českých evangelických stavů proti katolické dynastii Habsburků, bylo od počátku zrrejmé, že nepůjde o konflikt lokální, ale že bude mít evropskou dimenzi. Obě znepřátelené strany kromě zahájení zbrojení začaly usilovat o co nejširší zahraniční podporu - pražská direktorská vláda především mezi svými souvěrci luteránského či reformovaného vyznání, Vídeň u mocností katolických. V tomto směru byli císař Matyáš (1611-1619) a po jeho smrti dne 20. března 1619 jeho nástupce Ferdinand Štýrský vždy o krok napřed, nebot' mohli s jistotou spoléhat na pomoc svých španělských př́ibuzných. Mimořádné úsilí pak oba bloky věnovaly státům, které v té době sousedily se zeměmi Koruny české. Českým stavům sice poskytl pomoc rýnský falckrabě Fridrich V. z dynastie Wittelsbachů, jemuž patřila rovněž Horní Falc, ovšem sympatie, natož podporu jeho bavorského souseda a př́buzného vévody Maxmiliána I., horlivého katolíka, z podstaty věci získat nemohly. Mnichov se však zpočátku odmítavě stavěl i k nabídkám Habsburků, kteří před nedávnem fakticky pohřbili jeho projekt Katolické ligy. Tento spolek německých knížat vznikl ve dnech 3.-10. července 1609 pod bavorským předsednictvím jako protiváha Protestantské unie založené o rok dříve, ${ }^{1}$ ale Vídeň v něm i přes ideovou spřízněnost spatřovala nebezpečné mocenské ohnisko ohrožující její postavení. Právě její tlak vedl roku 1616 Maxmiliána Bavorského ke složení hodnosti představeného Katolické ligy, resp. její hornoněmecké části, což spolu s rivalitou mezi touto a rýnskou složkou reprezentovanou arcibiskupstvím mohučským vedlo k jejímu faktickému zániku. To Bavorsko nutně chápalo jako křivdu, k jejíž nápravě otevřelo české stavovské povstání a s ním spojená tíseň habsburského tábora prostor. Tato taktika totiž dávala vévodovi Maxmiliánovi I. možnost zvyšovat svou cenu a stupňovat své politické a územní požadavky.

Úkolu přesvědčit bavorského vévodu, aby svůj stávající zdrženlivý postoj přehodnotil, se ujal sám Ferdinand Štýrský. Ten dne 11. července 1619 s početným doprovodem vyrazil z Vídně do Frankfurtu nad Mohanem, kde se tradičně scházeli kurfiřti k volbě rímského krále, a po osmi dnech dorazil do Mnichova. ${ }^{2}$ Maxmilián I. při jeho uvítání měl patrně možnost spatřit rovněž jeho dceru Marii Annu Habsburskou (1610-1665), v té době devítiletou, která se roku 1635 stane jeho druhou manželkou. Tomuto dynastickému sňatku nijak nebude překážkou věkový rozdíl mezi oběma partnery, který bude činit 27 let, ani jejich dvojnásobný blízký př́buzenský vztah, který bude řešen dispenzí. Matkou Ferdinanda II. totiž byla Marie Anna Wittelsbašská (1551-1608), dcera bavorského vévody Albrechta V.

NÖHBAUER, H. F. Die Chronik Bayerns. Dortmund: Chronik-Verlag, 1987, s. 207.

GINDELY, A. Dějiny českého povstání. Díl II. Praha: F. Tempský, 1878, s. 109-110. 
(1550-1579), jehož byl Maxmilián I. vnukem. Další Marie Anna (1574-1616), dcera bavorského vévody Viléma V. (1579-1597/1598) a zároveň sestra Maxmiliána I., byla roku 1600 provdána za Ferdinanda Štýrského, jemuž roku 1608 porodila následníka trůnu Ferdinanda III. Navíc se nově zvolený a korunovaný císař a bavorský panovník osobně znali ze studií na univerzitě v Ingolstadtu, která byla spravována jezuity. V neposlední řadě se oba cítili být povinni spolupracovat při obhajobě katolické víry a společně pocit'ovali averzi vůči jiným vyznáním, o čemž svědčil výrok připisovaný Ferdinandovi II., totiž že lepší je poušt' než země plná kacírự, ${ }^{3}$ s nímž se Maxmilián I. absolutně ztotožňoval. Jejich červencové setkání bylo patrně pouze kratičké, nebot' již dne 28 července 1619 dorazil Ferdinand II. do Frankfurtu nad Mohanem, kde byl o měsíc později zvolen a dne 9. září 1619 v chrámu sv. Bartoloměje korunován římským císařem. Kolegium volitelů při tomto aktu odmítlo jakékoli nároky českých evangelických stavů na dispozici s kurfiřtským hlasem Království českého, Ferdinandovi II. dokonce odevzdal hlas i zástupce Fridricha V., falckraběte rýnského, který byl ve dnech 26. a 27. srpna 1619 zvolen a vyhlášen novým českým panovníkem.

Když se nový císař vracel z úspěšné frankfurtské mise zpátky do Vídně, navštívil Maxmiliána I. v bavorské metropoli na počátku ř́ijna 1619 podruhé. Diplomatická jednání, která při této př́ležitosti ve dnech 2.-5. ř́jina 1619 proběhla, byla mnohem intenzivnější než sondování terénu před několika měsíci. Císařská i bavorská strana na ně delegovala vždy po dvou zástupcích. Za Ferdinanda II. jednal jeho zkušený diplomat Jan Oldřich z Eggenberku (1568-1634), jemuž asistoval dvorský místokancléř Linhart z Götze (1561-1640), na počátku téhož roku ustanovený a dosud ještě nevysvěcený biskup lavantský. Bavorský vévoda zastupováním pověřil dva členy své tajné rady - hraběte Jana z Hohenzollernu-Sigmaringenu (1578-1638) a Viléma Jochera (1565-1636), svého experta v oblasti práva. Tuto čtveřici pak doplnil ještě Eitel Fridrich z Hohenzollernu-Sigmaringenu (1582-1625), probošt kolínské katedrální kapituly a nejvyšší hofmistr kolínského metropolity Ferdinanda (1612-1650), což byl mladší bratr Maxmiliána I. Ten zastupoval nejen Kolín nad Rýnem, ale také tehdejšího arcibiskupa mohučského Jana Schweikharda z Kronbergu (1604-1626) a jeho trevírského kolegu Lothara Metternicha (1599-1623). Není bez zajímavosti, že tento zmocněnec tří duchovních kurfiřtů v duchovní sféře záhy překonal své zmocnitele - díky habsburským přímluvám byl Eitel Fridrich papežem Piem V. (1605-1621) v lednu 1621, tedy těsně před jeho smrtí, jmenován kardinálem, roku 1622 jej jeho nástupce Řehoř XV. (1621-1623) zařadil do nově zřízené kongregace pro šíření víry (Congregatio de Propaganda Fide) a roku 1623 byl zvolen osnabrückým biskupem.

Výsledkem práce této konference byla dohoda, označovaná podle místa svého vzniku jako mnichovská. ${ }^{4}$ Je datována dnem 8. ř́ijna 1619, ačkoli Ferdinand II. ji ratifikoval až 13. ř́ijna 1619. Z formálního hlediska jde o dokument skládající se z rozsáhlé preambule, šesti článků a stručného závěrečného ustanovení. Právě to obsahuje informaci, že byl osobně zpečetěn a vlastní rukou podepsán císařem Ferdinandem II. a vévodou Maxmiliánem I.

3 ALBRECHT, G. - PRINZ VON BAYERN, L. Ohne Bayern kein Bier. Ohne Bier kein Bayern. München: Volk Verlag, 2016, s. 174.

$4 \quad$ ZIEGLER, W. (ed.). Dokumente zur Geschichte von Staat und Gesellschaft in Bayern. Abteilung I. Band 2. Altbayern vom Frühmittealter bis 1800. München: C. H. Beck, 1992 (dále jen „Dokumente I/3/2“), č. 204, s. 862-865; LORENZ, G. (ed.). Quellen zur Vorgeschichte und zu den Anfängen des Dreißigjährigen Krieges. Darmstadt: Wissenschaftliche Buchgesellschaft, 1991, č. 65, s. 398-407. 
Jak již bylo naznačeno, na jeho vypracování se podílel také Eitel Fridrich z Hohenzollernu-Sigmaringenu jako vyslanec tř́i porýnských duchovních kurfiřtů. Jeho podpis na mnichovské dohodě z roku 1619 překvapivě chybí, ačkoli byl výslovně zmíněn v jejím úvodu. Evidentní nesoulad znění preambule a závěru této úmluvy, tedy zda je dvojstranná (Ferdinand II., Maxmilián I.) nebo pětistranná (Ferdinand II., Maxmilián I., tři electores ecclesiastici), ve své době patrně nikoho netrápil. Ostatně její ustanovení normativní povahy jednoznačně svědčila o tom, že jde o akt bilaterální, nebot' upravoval pouze vztahy mezi císařem na straně jedné a bavorským vévodou na straně druhé. Účast zástupce arcibiskupů z Kolína nad Rýnem, Mohuče a Trevíru při sjednání mnichovské dohody z roku 1619 naznačovala, že hlavní dvě smluvní strany konají s jejich vědomím a požehnáním. Pro úplnost nutno dodat, že v Mnichově byl v době jednání přítomen také španělský velvyslanec při vídeňském dvoře Íñigo Vélez de Guevara, známější spíše jako hrabě de Oñate, který - jak bude naznačeno později - nebyl na počátku října 1619 v bavorském hlavním městě pouhým pasivním pozorovatelem.

\section{Oficiální část}

V úvodní části preambule mnichovské dohody z roku 1619 jsou pochopitelně identifikovány smluvní strany. Kupodivu velmi stručná je titulatura Ferdinanda II., který dokonce ani není (na rozdíl od Maxmiliána I.) výslovně jmenován a je označen pouze jako „Jeho Veličenstvo císař římský a také král uherský a český“. Chybí tedy celá řada názvů hodností vztahujících se k alpským zemím i vedlejším součástem Koruny české, kde Ferdinand II. rovněž fakticky či alespoň nominálně vládl. Bavorský vévoda byl sice identifikován svým jménem a zemí, v níž panoval, vynecháno u něj však bylo označení „falckrabě rýnský“, který bavorští Wittelsbachové od 13. století standardně užívali, často dokonce přednostně, byt' od roku 1329 mu chyběl reálný obsah. Tyto mezery naznačují, že text vznikal narychlo a že méně podstatné věci a formality byly ponechány stranou.

Úvodní část mnichovské dohody také obsahuje důvod, proč byla sjednána - stalo se tak kvůli naléhavému a extrémnímu nebezpečí, v němž se ocitá řečený císařský majestát a rakouský dům, ale tím i všichni katoličtí stavové císařství a samo katolické náboženství (de praesentissimo et extremo periculo, in quo praedicta Caesarea Maiestatis ac Domus Austriatica, nec non per hoc omnes Catholici Status Imperii et ipsa Catholica religio versatur). Samotné nebezpečí sice nebylo specifikováno, ale z dobového kontextu bylo všem zcela jasné, že je dvojího druhu. První z nich bylo české stavovské povstání, které začalo více než před rokem a které ohrožovalo nejdůležitější pozici Habsburků ve střední Evropě. Daleko akutnější však byla hrozba rozšiření odboje také o další země středoevropské monarchie, především o Uhersko. Ferdinandovi II. byla zcela jistě cestou z Frankfurtu nad Mohanem do Mnichova doručena zpráva, že v září 1619 vpadl do Horních Uher sedmihradský kníže Gábor Bethlen, navzdory své notorické nespolehlivosti označovaný jako „nový Mithridates“. Ten díky podpoře místní nekatolické šlechty bez větších problémů prošel se svým vojskem až k Prešpurku, který nejprve oblehl a pak dne 14. října 1619 dobyl..$^{5}$ Ohrožení a následná ztráta velké části habsburských Uher, a to včetně jejich hlavního města, donutily Ferdinanda II. a jeho zástupce při vyjednávání s Bavorskem o parametrech mnichovské dohody $\mathrm{k}$ velkým ústupkům, $\mathrm{k}$ nimž by pravděpodobně jinak nebyli 
ochotni. Prakticky šlo o akceptaci všech zásadních bodů bavorského návrhu předloženého dne 8. ř́ijna 1619 v německé verzi Vilémem Jocherem. ${ }^{6}$ Mezinárodní dohoda z roku 1619 tak má spíše formu diktátu, jímž také byla. ${ }^{7}$

Za závažné omezení již tak značně oslabené autority císařské moci ve Svaté říši římské národa německého lze považovat souhlas Ferdinanda II. s reaktivací Katolické ligy, jejíž činnost jeho předchůdce Matyáš považoval za nežádoucí a neslučitelnou se Zlatou bulou Karla IV. Tento názor byl obsažen v císařské instrukci vydané z iniciativy kardinála a biskupa Melchiora Khlesla dne 3. dubna 1617 na Pražském hradě. ${ }^{8}$ Bavorsko však v té době členem Katolické ligy nebylo, nebot' ji bylo nuceno opustit již dne 14. ledna $1616,{ }^{9}$ aby však vzápětí (dne 27. května 1617) založilo společně s biskupstvím bamberským, würzburským a eichstättským, jakož i s proboštstvím ellwangenským, její jihoněmeckou verzi. ${ }^{10}$ Začátek českého stavovského ovšem donutil Vídeň její negativní postoj radikálně změnit.

Dne 26. ledna 1619 utvořili v Oberweselu kurfiřti mohučský, trevírský a kolínský spolu s biskupstvím würzburským, bamberským a špýrským na dobu šesti let defensní spolek na obranu katolické víry, ${ }^{11}$ čímž fakticky obnovili Katolickou ligu. O zhruba čtyři měsíce později, přesněji dne 31 . května 1619 , byla vytvořena další hornoněmecká aliance mezi Bavorskem, diecézemi Bamberg, Würzburg, Eichstätt a Augšpurk a proboštstvím Elwangen, k níž se dne 20. července téhož roku připojilo také biskupství kostnické, ${ }^{12}$ která měla zcela stejný účel jako oberweselská. První spolek vznikl ještě za života císaře Matyáše, druhý až po jeho smrti v období interregna. Habsburkové se proti těmto uskupením nijak nevymezili a jejich zrod pouze vzali na vědomí. Preambule mnichovské dohody z roku 1619 předchozí existenci či neexistenci Katolické ligy vůbec neřešila. Obecně a poněkud šroubovaně totiž konstatovala, že bavorský vévoda přebírá plné či snad spíše neomezené vedení katolické obrany a př́pravy (plenarium Directorium Catholicae defensionis et praeparationis). Císař Ferdinand II. a říššsí katoličtí stavové (reprezentováni zástupcem tř́ duchovních kurfiřtů) byli dokonce postaveni do role těch, kteří Maxmiliána I. o tuto službu žádají.

V návaznosti na preambuli specifikoval čl. I. mnichovské dohody z roku 1619, že římsko-německý panovník, resp. vídeňská (rakouská) větev habsburské dynastie, a řŕšští katoličtí stavové jsou povinni zamezit, aby bavorskému vedení Ligy v boji proti jejich nepřátelům byla kladena jakákoli omezení, a naopak zajistit mu v jeho úsilí svou maximální součinnost. Protihodnota byla celkem zřejmá - Maxmilián I. se zavázal, že za př́íspěvky členů Katolické ligy najme vojsko a, pokud mu to dovolí jeho bezpečnost a bezpečnost jeho spojenců, jím bude pomáhat císaři. ${ }^{13}$

6 Dokumente I/3/2, č. 203, s. 860-862.

7 HEILIGSETZER, G. Die Bayern in Oberösterreich (1620-1628). In: GLASER, H. (ed.). Um Glauben und Reich. Kurfürst Maximilian I. München: Hirmer Verlag, 1980, s. 417.

8 Dokumente I/3/2, č. 194, s. 839-840.

9 Dokumente I/3/2, č. 192 , s. 828-836.

10 Dokumente I/3/2, č. 195, s. 841-845.

11 WEISS, D. J. (ed.). Germania sacra. Die Bistümer der Kirchenprovinz Mainz. Das exemte Bistum Bamberg 3. Die Bischofsreihe von 1522 bis 1693. Berlin - New York: Walter de Gruyter, 2000, s. 367.

12 NEUER-LANDFRIED F. Die Katholische Liga. Gründung, Neugründung und Organisation eines Sonderbundes 1608-1620. Kallmünz: Michael Lassleben, 1968, s. 166-168.

13 KOŘÁN, J. a kol. Dějiny Čech a Moravy nové doby. Díl druhý. Praha: L. Mazáč, 1940, s. 442. 
Mnichovská dohoda z roku 1619 tak bez jakýchkoli pochybností vyjadřovala souhlas panovníka Svaté říše rrímské národa německého s fungováním vojenské aliance, která mu nebyla přímo podřizena a vystupovala spíše jako jeho partner a spojenec. Po jejím uzavření nic nebránilo konání sjezdu katolických říšských knížectví, který se sešel dne 5. prosince 1619 ve Würzburgu. Tento kongres byl obeslán jak zástupci oberweselského, tak hornoněmeckého spolku. Nešlo zdaleka o všechny státy Svaté říše římské národa německého, v nichž byl katolicizmus státním náboženstvím. Své zástupce do Würzburgu nevyslalo mj. biskupství pasovské, v němž vládl biskup Leopold V. (1598-1625), bratr Ferdinanda II., biskupství freisinské, u něhož byla averze jeho ordinářů vůči Bavorsku větší než ochota hájit konfesní zájmy, velice ambivalentně se chovalo rozlehlé arcibiskupství salcburské, které - byt' se od roku 1619 (poprvé ve dnech 25.-30. srpna 1619 v Eichstättu) účastnilo sjezdů hornoněmecké partikulární části Katolické ligy - bylo zdrženlivé k užší formě spolupráce, nezapojilo se ani proboštství berchtesgadenské, byt' v jeho čele stál Ferdinand Bavorský, bratr Maxmiliána I. a zároveň arcibiskup kolínský, biskup lutyšský, hildesheimský, münsterský a paderbornský a také opat malmédsko-stabelský (až na Kolín nad Rýnem ostatní jeho državy zachovávaly neutralitu).

Dne 14. prosince 1619 byla ve Würzburgu ratifikována dohoda o kooperaci oberweselské a hornoněmecké části Katolické ligy. ${ }^{14}$ Předpokládalo se, že bude účinná šest měsíců, následně však byla prodlužována. Bylo ujednáno, že v čele této organizace budou společně mohučský arcibiskup a řŕšský kancléř Jan Schweikhard z Kronbergu a bavorský vévoda Maxmilián I., přičemž vedení vojenských operací bylo svěřeno pouze druhému jmenovanému. Bavorský panovník ovšem faktické velení přenechal generálu Janu Tserclaemu Tillymu, který se již osvědčil jak v habsburských (před rokem 1610), tak ligistických a bavorských službách (po roce 1610). ${ }^{15}$ Za zvlášt' důležité pak lze označit stanovení velikosti alianční armády. Ta měla mít celkem 21000 pěších a 4000 jízdních vojáků, přičemž na jednotlivé členy Katolické ligy byly rozepsány přesné kvóty. Na Bavorsko připadlo najmutí a financování 6000 pěšáků a 1000 rejtarů, stejný počet pak mělo zabezpečit oberweselské direktorium, hornoněmečtí členové pak měli vypravit 7000 pěších a 1800 jízdních, zbytek (2 000 pěších a 200 jízdních) bavorský říšský kraj. Nakonec byla ligistická armáda ještě o něco větší.

V ustanovení čl. II. mnichovské dohody se císař a jeho dynastie zavazovali, že nebudou bez vědomí Bavorska vyjednávat a korespondovat s nepř́itelem, obecně označeným jako protestanti (Protestantes). Tím byli patrně míněni jak evangeličtí stavové čeští, tak také říšští. S těmito subjekty nesměl císař bez vědomí, vůle a součinnosti Mnichova uzavřít žádnou dohodu, zvláště ne mírovou ani o dočasném klidu zbraní. Vídeň se tak fakticky ve značném rozsahu zřekla samostatné říšské politiky.

Čl. III. mnichovské dohody z roku 1619 řešil otázku válečných náhrad. Latinsky sepsaná mezinárodní dohoda $\mathrm{v}$ tomto př́ípadě užívá německý termín Landschaden, tedy újmy způsobené zemi. Tím byly míněny nejen škody eventuálně způsobené Bavorsku vpádem cizích vojsk, ale rovněž náklady, které vyplývaly z jeho členství v Katolické lize. Povinnou osobou byl v tomto př́padě opět nejen samotný Ferdinand II., který mnichovskou

14 Dokumente I/3/2, č. 211, s. 874-879.

15 HARTMANN, P. C. Bayerns Weg in die Gegenwart. Vom Stammesherzogtum zum Freistaat heute. Regensburg: Friedrich Pustet, 1989, s. 228. 
dohodu uzavřel, ale také celá rakouská větev habsburské dynastie (Caesarea Sua Maiestatis cum tota sua Domo). Maxmilián I. si vymínil více než přiměřenou záruku, že tento závazek bude splněn. V současné české historické literatuře se vícekrát vyskytl názor, že mnichovskou dohodou z roku 1619 se Vídeň zavázala Mnichovu za jeho pomoc zastavit Horní Rakousy. ${ }^{16}$ Tak tomu nakonec skutečně bylo, nicméně ujednání z roku 1619 se o tomto arciknížectví vůbec nezmiňovalo a rozsah zástavního práva definovalo mnohem šíŕeji - mohlo jít dokonce o rakouské země jako takové, což byly nejen Rakousy Horní, ale také Dolní, Korutany, Štýrsko, Kraňsko, Tyrolsko a državy ve Švábsku. Bavorsko jistě mělo k Hornímu Rakousku geograficky nejblíže, totéž však lze konstatovat i o Tyrolsku. Většina této země byla ostatně bavorská do 11. století, Wittelsbachové v ní posléze panovali v letech 1342-1363, některé její části (Kitzbühel, Rattenberg, Kufstein) pak drželi až do roku 1505. ${ }^{17}$

Přesná specifikace zástavy byla provedena až s odstupem půldruhého roku. Listinou ze dne 8. března 1621 císař Ferdinand II. upřesnil, že Maxmiliánu I. zastavuje arciknížectví Rakousy nad Enží (Erzherogthumb Österreich ob der Enns), ${ }^{18}$ jehož hranice překročila ligistická vojska dne 24. července $1620,{ }^{19}$ aby v něm pacifikovala stavovskou revoltu. Tuto část alpských držav, kterou se bavorský vévoda jako budoucí zástavní věřitel zavázal odejmout nepřátelským silám, měl dle čl. V. mnichovské dohody z roku 1619 užívat do doby, dokud mu nebudou kompenzovány všechny náklady a škody. Po tuto dobu měla být Maxmiliánem I. a jeho dědici respektována veškerá zeměpanská práva Habsburků $\mathrm{k}$ těmto državám, ${ }^{20}$ zvláště pak komorní př́ijmy ze solního, horního a celního regálu (Bona Principis Cameralia haec: salinae, fodinae et telonia). Význam tohoto ustanovení, které alespoň částečně chránilo hospodářské zájmy císaře, však silně znehodnocoval dovětek, že toto ujednání neplatí, pokud ostatní prříjmy [ze zemí tvořících zástavu] nebudou k náhradě škod dostatečné (nisi ad dictam restitutionem alia bona non suffecerint). Tuto skvělou př́ležitost si Maxmilián I. nenechal ujít a navzdory nářkům císaře Ferdinanda II. neváhal sáhnout na zisky z hornorakouských solních dolů. ${ }^{21} \mathrm{Na}$ mnichovskou dohodu z roku 1619 ve věci zástavních práv navázala úmluva uzavřená dne 6 . dubna 1623 v Řezně, ${ }^{22}$ kterou byla vyčíslena výše dluhů Ferdinanda II. vůči Maxmiliánovi I. částkou 12 miliónů zlatých. Do jejího vypořádání (o tom, že by mohla být tato astronomická částka splacena, nemohl nikdo uvažovat) mělo Bavorsko podržet kromě Horních Rakous také Horní Falc, přičemž na každou z těchto zemí připadalo 6 miliónů zlatých. V následujících pěti letech narostla dlužná částka úročená $5 \%$ ročně o další milión zlatých. Zbývá dodat, že ujednání o Horní Falci z roku 1623 šlo jednoznačně nad rámec mnichovské dohody z roku 1619, která připouštěla pouze zástavu rakouských zemí, nicméně ani jedné ze stran to nijak

16 VEBER, V. a kol. Dějiny Rakouska. Praha: Nakladatelství Lidové noviny, 2010, s. 270-271; UHLÍR̆, D. Drama Bílé hory. Česká válka 1618-1620. Brno: Press, 2017, s. 71; KUČERA, J. P. 8. 11. 1620. Bílá hora. O potraceni starobylé slávy české. Praha: Havran, 2003, s. 121.

17 HARTMANN, c.d., s. 110, s. 112 a s. 212.

18 Dokumente I/3/2, č. 223, s. 896-897.

19 KAVKA, F. Bílá hora a české dějiny. Praha: Garamond, 2003, s. 261.

20 NEUER-LANDFRIED, c. d., s. 179.

21 FRANZ. Die Politik Maximilians I. von Bayern und seiner Verbündeten 1618-1951. Erster Teil, Erster Band. Januar 1618 - Dezember 1620. München - Wien: R. Oldenbourg, 1966, s. 246.

22 Dokumente I/3/2, č. 241, s. 939-943. 
nevadilo - pro Ferdinanda II. to bylo výhodné, nebot' Horní Falc nepatřila k jeho dědičným državám, Maxmilián I. pak dostal do držení území, které hodlal spojit s Bavorskem.

Mnichovská dohoda z roku 1619 v čl. IV. počítala rovněž s eventualitou, že spojenecká aliance Vídeň - Mnichov v konfrontaci s českými evangelickými stavy a jejich spojenci neuspěje a že bavorský vévoda v boji přijde o své državy či jejich část. Pro ten př́pad bylo dohodnuto, že mu císař Ferdinand II. poskytne účinnou pomoc ve znovudobytí př́slušného území a pokud to nebude možné, že mu ze svých alpských zemí postoupí rovnocennou náhradu. Ferdinand II. v tomto případě nepřímo projevil, že k jednotlivým částem svého dědictví po císaři Matyášovi má odlišný vztah a že jsou mu bližší spíše země české než rakouské, byt' při jeho úvahách evidentně rozhodovalo hledisko ekonomické. Tento př́ístup však neměl dlouhého trvání, nebot' tentýž panovník již dne 21 . března 1620 dohodou s kurfiřtem Janem Jiřím slíbil Sasku jako kompenzaci za přechod do císařského tábora obě Lužice, ${ }^{23}$ integrální součást Koruny české.

Konečně v ustanovení čl. VI. mnichovské dohody z roku 1619 smluvní strany společně konstatovaly, že pokládají za nezbytné a vhodné, aby velitel císařského vojska (v textu nejmenován, míněn Charles Bonaventure de Longueval, hrabě Buquoy) udržoval spojení a písemný kontakt s Maxmiliánem Bavorským. Ke škodě věci nebyl nijak upraven vztah mezi velením ligistické a císařské armády. Když pak dne 8. záŕí 1620, přesně jedenáct měsíců po uzavření mnichovské dohody z roku 1619, došlo u Oberndorfu v Dolním Rakousku ke spojení těchto vojsk ${ }^{24}$ a společnému tažení přes jižní a západní Čechy k hlavnímu městu Království českého, docházelo mezi nimi k mnoha konfliktním situacím. Generál Buquoy považoval jakoukoli formu podřízenosti za osobní ponížení, tím spíše, že Maxmilián I. byl spíše politik než voják. Rozpory v kolektivním stylu vedení císařsko-ligistickou armády však bledly ve srovnání s řízením vojsk protivníka, v němž se střetávalo daleko více osob a zájmů (Kristián z Anhaltu, Jindřich Matyáš Thurn, Jiří Fridrich Hohenlohe, Petr Arnošt z Mansfeldu, Jan Jiř́i Krnovský, Gábor Bethlen).

\section{Tajná část}

Mnichovská dohoda z roku 1619 však měla kromě písemné části ještě jednu neveřejnou. Ta dokonce neměla ani písemnou formu. Nejdůležitější ústupky totiž císař Ferdinand II. učinil Maxmiliánu I. pouze ústně, když slíbil bavorskému vévodovi, že na něj přenese falckou kurfiřtskou hodnost a že mu postoupí ta území, která dobude na Fridrichovi V. ${ }^{25}$ Mezi smluvními stranami evidentně existovala obava, že tato ujednání budou vnímána jako kontroverzní a že jejich předčasné prozrazení by mohlo být využito proti nim. U obou je třeba se zastavit a zmínit se o nich podrobněji.

Získání kurfiřtské hodnosti bylo pro bavorské Wittelsbachy mimořádně důležitou záležitostí. Ačkoli jejich dědičné državy patřily k nejrozsáhlejším světským knížectvím ve Svaté říši římské, byli z exkluzivního klubu volitelů panovníka tohoto státního útvaru vyloučeni roku 1356 Zlatou bulou Karla IV. (kap. 4, čl. 1). ${ }^{26}$ Toto uspořádání pokládali

23 HOENSCH, J. Geschichte Böhmens. München: C. H. Beck, 1987, s. 222.

24 CHALINE, O. Bílá hora. Praha: Univerzita Karlova, 2013, s. 113.

25 KRAUS, A. Geschichte Bayerns. Von den Anfängen bis zur Gegenwart. München: C. H. Beck, 2013, S. 238.

26 FRITZ, W. D. (ed.). Monumenta Germaniae Historica. Constitutiones et acta publica imperatorum et regum. Tomus XI. Weimar: Böhlau, 1978-1992, s. 581. 
za nespravedlivé, nebot' v letech 1214-1329 měli v držení Horní i Dolní Falc a otázku dispozic s kurfiřtským hlasem s nimi spojeným upravili rodinnou dohodou ze dne 4. srpna 1329 uzavřenou v italské Pavii (Hausvertrag von Pavia). ${ }^{27}$ Dle jejího čl. VII. se mělo právo na volbu rrímského krále střídat mezi hornobavorskou a falckou větví wittelsbašské dynastie, které se zároveň rozdělily o území, které ovládaly. Účastníkem této úmluvy a zároveň jejím garantem byl římský císař Ludvík IV. Bavor (1314-1347), který byl od roku 1294 falckrabím rýnským a vévodou hornobavorským, od roku 1340/1341 pak i dolnobavorským. Karel IV. ovšem úmyslně bavorské Wittelsbachy pominul a dal přednost jejich falckým př́buzným, z jejichž rodu pocházela jeho druhá manželka Anna.

Panující bavorská dynastie ovšem v roce 1619 kurfiřtským hlasem již disponovala, byt' nebyl spojen s jejími dědičnými državami. Roku 1582 totiž odpadl od katolické víry kolínský arcibiskup a kurfiřt Gebhard Truchseß z Waldburgu-Trauchburgu, který se následně pokusil prosadit s pomocí nizozemských stavů ve svých porýnských državách reformaci. ${ }^{28}$ To bylo zcela $\mathrm{v}$ rozporu se zásadou stanovenou v augšpurském náboženském míru z roku 1555, totiž že katolické vyznání v církevních říšských knížectvích je neměnné (reservatum ecclesiasticum). ${ }^{29}$ Papež Řehoř XIII. proto arcibiskupa dne 1. dubna 1583 suspendoval a exkomunikoval, načež kolínská katedrální kapitula dne 23. května 1583 zvolila novým metropolitou Arnošta, bratra bavorského vévody Viléma V. a biskupa freisinského (od 1566), hildesheimského (od 1573) a lutyšského (od 1581), jakož i opata malmédsko-stabelského (od 1581). ${ }^{30}$ Následujících téměř 200 let, až do roku 1761, zůstalo arcibiskupství kolínské spolu s dalšími dolnoněmeckými biskupstvími pevně v rukou bavorských princů, kteří vykonávali biskupské funkce. ${ }^{31}$ Dlouhodobé ovládnutí Kolína nad Rýnem, označovaného jako bavorská sekundogenitura (bayerische Sekundogenitur), ${ }^{32}$ však Mnichovu nestačilo.

Někdy na přelomu zář́i a října 1619 sepsal Kryštof Gewold, tajný sekretář Maxmiliána I., právní stanovisko, které mělo dokazovat nárok bavorských Wittelsbachů na udělení kurfiřtské hodnosti. ${ }^{33} \mathrm{Na}$ prvním místě samozřejmě zmínil pavijskou úmluvu, připomenul také neurčité sliby učiněné Bavorsku v této věci římskými císaři, zvláště pak Karlem V. (1519-1556) v roce 1546. Tehdy během války se šmalkaldským spolkem totiž rímsko-německý císař připustil řezenskou smlouvou ze dne 7. června 1546 možnost translace kurfiřtské hodnosti z Falce na Bavorsko, jemuž tehdy vládl Vilém IV. (1508-1550), nakonec ji však neprovedl. ${ }^{34}$ Gewoldův elaborát byl zcela jistě použit při jednáních předcházejících uzavření mnichovské dohody na počátku října 1619.

27 AY, K.-L. (ed.). Dokumente zur Geschichte von Staat und Gesellschaft in Bayern. Abteilung I. Band 2. Altbayern vom Frühmittelalter bis 1800. Altbayern von 1180 bis 1550. München: C. H. Beck, 1977, č. 66, s. $124-128$.

28 LUTZ, H. Reformation und Gegenreformation. München - Wien: R. Oldenbourg, 1982, s. 77.

29 CAMPENHAUSEN, A. Staatskirchenrecht. München: C. H. Beck, 1996, s. 15.

30 LOJEWSKI, G. Bayerns Kampf um Köln. In: GLASER, c. d., s. 44.

31 BAUR, A. Kleine bayerische Kirchengeschichte. Donauwörth: Ludwig Auer, 1964, s. 66.

32 BOSL, K. Bayerische Geschichte. München: W. Ludwig Buchverlad, 1990, s. 159.

33 Dokumente I/3/2, č. 206, s. 855-868.

34 HUBENMEISTER, B. Bayerische Geschichte. Rosenheim: Rosenheimer, 2013, s. 216-217; LANZINNER, M. 25. Februar 1623. Die Regensburger Deputationstag. Bayern wird Kurfürtstentum. In: SCHMID, A. - WEINGAND, K. (eds.). Bayern nach Jahr und Tag. 24 Tage aus der bayerischen Geschichte. München: C. H. Beck, 2007, s. 257. 
Ferdinand II. jistě nebyl z návrhu na podstatnou změnu základního předpisu upravujícího říšské záležitosti nadšen. Krizový stav, v němž se nacházel, mu však nedával na vybranou. Slib, že na Maxmiliána I. přenese falckou kurfiřtskou hodnost, přesto učinil a nakonec také dodržel, byt' byl učiněn ústně a neveřejně. O tom, co jej k tomu vedlo, nejlépe svědčí písemnost jeho kanceláře ze dne 14. ř́jjna 1619. ${ }^{35}$ Příslušný písař, který ji koncipoval, v původní verzi napsal, že rozhodnutí o translaci kurfiřtského hlasu z Falce na Bavorsko, učinil Ferdinand II. „,bezpochyby pobídnut od Boha“" (a Deo absque dubio impulsus). V tomto místě jej však panovník opravil a instruoval jej, aby př́íslušnou formulaci změnil „na radu vyslance krále“ (ex consilio Legati Regis), čímž mínil španělského velvyslance hraběte Oñata. ${ }^{36}$ Čerstvě zvolený císař tímto krokem překročil své právem stanovené kompetence a věděl dobře, že tím proti sobě patrně poštve německá knížata bez ohledu na jejich konfesi, nicméně se zřetelem na svou choulostivou situaci neměl jinou volbu. ${ }^{37} \mathrm{Na}$ druhou stranu nešlo o první př́ípad tohoto druhu. Jako precedens, na který Maxmilián I. musel upozornit, bylo možné označit obměnu kurfiřtského hlasu, k níž došlo v rámci dynastie saských Wettinů roku 1547 na ř́šském sněmu v Augšpurku. Tehdy byl hlas volitele panovníka Svaté říše římské národa německého odňat Janu Fridrichovi I., vůdci šmalkaldského spolku poraženého krátce předtím v bitvě u Mühlbergu (24. dubna 1547) z ernestinské větve saského vládnoucího rodu, a předán jeho př́ibuznému Mořicovi $\mathrm{z}$ albertinské linie, který byl straníkem císaře Karla V. ${ }^{38}$

To, že bavorský vévoda aspiruje na kurfiřtskou hodnost, tehdejší Evropa zaregistrovala o několik měsíců později. Dne 16. května 1620 vydal Ferdinand II. ve Vídni ve prospěch Maxmiliána I. privilegium de non appellando, ${ }^{39}$ jímž Bavorsko vyňal z pravomoci říšského komorního soudu. Této výsadě se ve Svaté říši rrímské národa německého netěšil nikdo jiný než kurfiřti. V této listině se v označení Maxmiliána I. objevuje, dokonce na prvním místě, titul falckrabího rýnského (Pfaltzgraue bey Rhein), vynechaný v mnichovské dohodě z roku 1619, který začínal nabývat na důležitosti.

Nezbytnou podmínkou pro změnu v kolegiu kurfiřtů bylo to, že falckrabě Fridrich V. na sebe přijetím svatováclavské koruny uvalí říšskou klatbu. Tato skutečnost záhy nastala. Rýnský falckrabě totiž začal používat český královský titul ode dne 23. ř́jna 1619, kdy se ve Waldsassenu setkal s deputací konfederovaných stavů, ${ }^{40}$ následně pak byl ve dnech 4.-7. listopadu 1619 spolu s chotí Alžbětou Stuartovnou korunován. ${ }^{41}$ Ferdinand II. ani za této situace s uvalením ř́ršského achtu nepospíchal a patrně čekal, jak bude mnichovská dohoda z roku 1619 ze strany Bavorska plněna a jak se budou vyvíjet válečné operace.

35 Dokumente I/3/2, č. 207, s. 868.

36 SPINDLER, M. - KRAUS, A. a kol. Handbuch der bayerischen Geschichte. Zweiter Band. Das Alte Bayern. Der Territorialstaat vom Ausgang des 12. Jahrhunderts bis zum Ausgang des 18. Jahrhunderts. München: C. H. Beck, 1988, s. 425.

37 PANTLE, CH. Der Dreißigjährige Krieg. Als Deutschland in Flammen stand. Berlin: Ulstein Buchverlag, 2017, s. 28.

38 JUNKELMANN, M. Maximilian I. von Bayern. Der eiserne Kurfürst. Regensburg: Friedrich Pustet, 2017, s. 135 a s. 147.

39 Dokumente I/3/2, č. 213, s. 880-882.

40 ADAMOVÁ, K. První česká federativni ústava z roku 1619. Praha - Plzeň: Ústav státu a práva, 2009, s. 107.

41 ČORNEJOVÁ, I. a kol. Velké dějiny zemi Koruny české. Svazek VIII. 1618-1683. Praha - Litomyšl: Paseka, 2008, s. 46. 
Toto opatření bylo vyhlášeno až dne 29. ledna 1621 (př́islušná listina byla antedatována k 22. lednu $)^{42}$ a bylo obsáhle zdůvodněno hrubým porušováním říšského právního řádu a podporou poskytovanou českým evangelickým stavům. Kromě českého zimního krále se obdobné opatření dotklo také Kristiána z Anhaltu, jeho velitele v bitvě na Bílé hoře a rovněž jeho místodržícího v Horní Falci (od 1595), Jiř́ho Fridricha Hohenloheho a markrabího Jana Jiř́iho Krnovského. ${ }^{43}$ Exekucí proti Fridrichovi V. byl mandátem ze dne 1. února 1621 pověřen bavorský vévoda. ${ }^{44}$

Za toho stavu již nic nebránilo, aby Ferdinand II. Fridrichovi Falckému, „který sám sebe nazývá kurfiřtem a falckrabím rýnským“ (český královský titul pochopitelně Víden̆ nikdy uznat nemohla), tyto hodnosti odňal a předal je Bavorsku. K tomu došlo dne 22. září $1621,{ }^{45}$ avšak stále ještě tajně. Adresáty tohoto privilegia byli v první řadě stávající panující bavorský vévoda Maxmilián I. a jeho mužští dědicové (Maximilian Hertzog zu Bayern, und seiner L. Mänlichen lehens Erben), sekundárně pak jeho bratři a jejich mužští dědicové (seiner L. Gebrüdern und deren mänlichen lehens Erben). Př́íslušní sourozenci sice nebyli jmenováni, ale všeobecně se vědělo, že jde o kolínského arcibiskupa Ferdinanda a budoucího leuchtenberského lankrabího Albrechta VI. Maxmilián I. ovšem v této době žádného syna neměl (jeho následník trůnu se narodil až roku 1636), ${ }^{46}$ u jeho bratra Ferdinanda, vysoce postaveného církevního hodnostáře, se plození dětí nepovažovalo za žádoucí, pouze Albrecht VI. disponoval syny Karlem Janem Františkem (1618-1640) a Ferdinandem Vilémem (1620-1629), posléze pak ještě Maxmiliánem Jindřichem (1621-1688), který se roku 1650 stane arcibiskupem a kurfiřtem kolínským, a Albrechtem Zikmundem (1623-1685), budoucím biskupem řezenským a freisinským.

K oficiálnímu předání hodnosti kurfiřta spolu s funkcemi říšského vikáře a arcistolníka pak došlo dne 25. února 1623 na říšském sněmu v Řezně. ${ }^{47} \mathrm{Na}$ první pohled Mnichov s tímto aktem nemohl být stoprocentně spokojen - byla totiž udělena pouze ad personam, což v případě smrti Maxmiliána I. znamenalo přinejmenším právní nejistotu. Ferdinand II. nemohl v této záležitosti nebrat ohled na námitky Saska a Braniborska, které znepokojoval pokles počtu protestantských členů kolegia volitelů římsko-německého panovníka. Aby byl tento odpor zlomen či alespoň oslaben, uzavřeli císař a bavorský vévoda den předtím tajnou dohodu, že o případné dědičnosti dodatečně rozhodne zvláštní kongres kurfiřtů. Vzhledem k tomu, že hlasem českého krále disponoval Ferdinand II. a že bavorským a kolínským kurfiřtem byli Maxmilián I. a jeho bratr Ferdinand, by k většině chyběl pouze jediný hlas, který by bez větších potíží dodali arcibiskup mohučský nebo jeho trevírský kolega, popřípadě oba. Pokud by k příslušnému rozhodnutí došlo ještě za života Maxmiliána I. a bylo by kladné, přechod kurfiřtské hodnosti by proběhl v souladu s tímto ujednáním bez problémů. Pro př́ípad, že by se volitelé rímsko-německého panovníka přiklonili na stranu Fridricha V. Falckého (což bylo z podstaty věci vyloučené), nemělo být nově získané postavení Maxmiliána I. až do jeho smrti dotčeno. Kdyby Maxmilián I. zemřel dříve, než kurfiřti vydají konečné stanovisko, slíbil Ferdinand II., že bude respektovat

\footnotetext{
42 LORENZ, c. d., s. 519-533.

43 WILSON, P. H. Der Dreißigjährige Krieg. Stuttgart: Theiss, 2017, s. 400-401.

44 LORENZ, c. d., s. 533-537.

45 Dokumente I/3/2, č. 229, s. 912-915.

46 SCHROTT, L. Die Herrscher Bayerns. München: Süddeutscher Verlag, 1966, s. 131.

47 Dokumente I/3/2, č. 239, s. 935-938.
} 
závěry svého výnosu ze dne 22. ̌ríjna 1621 s posloupností bavorského kurfiřtského titulu v mnichovské linii Wittelsbachů. 48

K udělení dědičné kurfiřtské hodnosti Bavorsku došlo roku 1628. Do té doby opoziční Sasko a Braniborsko své negativní stanovisko s kurfiřtskou hodností Maxmiliána I. přehodnotily - již v červenci 1624 vyjádřily souhlas Drážd'any, v květnu o tři roky později i Berlín. ${ }^{49}$ Závěry mühlhausenského sjezdu kurfirrtů konaného ve dnech 18 . ř́ijna - 12. listopadu 1627 jasně naznačovaly, že Ferdinand II., tehdy ostatně na vrcholu moci, může přistoupit $\mathrm{k}$ definitivnímu vypořádání svých závazků vyplývajících z mnichovské dohody $\mathrm{z}$ roku 1619.

\section{Konečné vypořádání závazků}

Smluvní strany mnichovské dohody z roku 1619 nemohly mít, co se týče jejího plnění, důvod k zásadním stížnostem. Z těch všeobecně známých historických událostí, které se v jejím důsledku udály, lze stručně připomenout alespoň tyto nejvýznamnější:

- dne 3. srpna 1620 Maxmilián I. jako zástupce Katolické ligy s francouzskou diplomatickou pomocí ulmskou smlouvou neutralizoval Protestantskou unii, ${ }^{50}$ která v české fázi třicetileté války neposkytla Fridrichovi Falckému žádnou účinnou pomoc;

- rok, měsíc a den po uzavření mnichovské dohody z roku 1619 po vítězství na Bílé Hoře vstoupila císařsko-ligistická vojska do Prahy;

- přesně dva roky po uzavření mnichovské dohody z roku 1619 se armádě Katolické ligy vzdal Amberg, hlavní město Horní Falce; ${ }^{51}$

- dne 19. záŕí 1622 po vítězstvích u Wimpfenu (6. května 1622) a Höchstu (20. června 1622) obsadily sbory Katolické ligy se španělskou pomocí Heidelberg, centrum Dolní Falce. $^{52}$

Právě ovládnutí Horní a Dolní Falce, držav Fridricha V. spadlých po vyhlášení achtu nad ním na Svatou říši římskou národa německého, Katolickou ligou bylo předpokladem pro realizaci druhého tajného ujednání mnichovské dohody z roku 1619. Dne 22. února 1628 v Mnichově uzavřel císařský diplomat Maxmilián z Trautmansdorfu se čtyřmi zmocněnci bavorského kurfiřta směnnou smlouvu (Tauschvertrag), ${ }^{53}$ dne 4 . března 1628 pak Ferdinand II. vydal na Pražském hradě zvláštní listinu o koupi a předání (Kauf- und Übergabebrief), ${ }^{54}$ které řešily nároky Maxmiliána I. za poskytnuté vojenské služby ve výši 13 miliónů zlatých vůči Vídni. Bavorským Wittelsbachům byla dědičně propůjčena Horní (s výjimkou měst Parkstein, Pleystein a Weiden s okolím, které patřily vévodství falc-neuburskému) a Dolní Falc, na oplátku však Habsburkům vrátili Horní Rakousy (k předání došlo dne 5. května 1628) a zřekli se nároku na jakékoli finanční plnění. Nadto bylo k Bavorsku již roku 1625 připojeno město Cham s okolím, ${ }^{55}$ které od něj bylo jako zástava

48 ALBRECHT, D. Maximilian I. von Bayern 1573-1651. München: R. Oldenbourg, 1998, s. 570.

49 MESSINGER, S. Die Übertragung der pfälzischen Kurwürde auf das Herzogtum Bayern: Rechtliche, zeremonielle und politische Probleme. Münster: LIT Verlag Münster, 2015, s. 89.

50 Dokumente I/3/2, č. 216, s. 886-888.

51 ALBRECHT, c. d., s. 555.

52 FUKALA, R. Tricetiletá válka 1618-1648. I. díl. 1618-1629. České Budějovice: Veduta, 2018, s. 91 a s. 94.

53 Dokumente I/3/2, č. 272, s. 999-1006.

54 Dokumente I/3/2, č. 273, s. 1006-1010.

55 Dokumente I/3/2, č. 251, s. 959-960. 
odtrženo roku $1352 .{ }^{56}$ Dále bylo dohodnuto, že pokud by dynastie panující v Bavorsku vymřela a v důsledku toho by obě Falce přešly na její př́ibuzné či by spadly jako uprázdněné léno na Říši, byla by tato ztráta Bavorsku ve výši 13 miliónů zlatých s př́slušenstvím kompenzována císařem či jeho nástupci. V návaznosti na anexi většiny hornofalckého území předal dne 25 . března 1630 Ferdinand II. Bavorsku také česká léna v tomto prostoru. ${ }^{57}$

Horní a Dolní Falc byla roku 1628 Maxmiliánu I. udělena v léno se všemi právy a povinnostmi, tedy také s dědičnou kurfiřtskou hodností. To o dvacet let později potvrdila také osnabrücká mírová smlouva mezi Svatou říší římskou národa německého a Švédskem ze dne 24. ř́jina 1648 (čl. IV. odst. 3), byt' ta pro Bavorsko znamenala zmenšení jeho územních zisků o Dolní Falc vrácenou Karlu Ludvíkovi, synovi Fridricha V., spolu s nově zř́żeným osmým kurfiřtským hlasem (čl. IV. odst. 5). ${ }^{58}$ Odměna Bavorsku za uzavření mnichovské dohody z roku 1619 tak sice byla poněkud redukována, přesto stále byla pravděpodobně o dost větší, než původně jeho vládce a diplomaté v druhém roce třicetileté války očekávali.

Dlužno doplnit, že osud Fridricha Falckého, tedy zbavení všech držav a hodností, se s odstupem času u jeho mnichovských wittelsbašských př́ibuzných téměř opakoval. Když roku 1701 vypukla válka o španělské dědictví, postavil se tehdejší bavorský kurfiřt Maxmilián II. Emanuel (1679-1726), vnuk Maxmiliána I., proti středoevropské habsburské monarchii. Ta však s anglickou pomocí jeho vojska posílená o francouzský pomocný sbor rozdrtila dne 17. srpna 1704 v bitvě u Hochstädtu ${ }^{59}$ a následně v letech 1704-1705 okupovala celé Bavorsko. Dne 29. dubna 1706 pak císař Josef I. (1705-1711) vyhlásil nad Maxmiliánem II. Emanuelem pro spojenectví s říšským nepřítelem (Francie) říšský acht (poslední v dějinách Svaté říše římské národa německého) a zbavil jej všech zemí a hodností, tedy i kurfiřtské, jež byla předána spolu s Horní Falcí Janu Vilémovi, vévodovi falc-neuburskému, ${ }^{60}$ samotnému starému Bavorsku (Altbayern) pak reálně hrozilo pohlcení Habsburky. Pouze díky Ludvíkovi XIV. byly Bavorsko, Horní Falc i titul kurfiřta Maxmiliánovi II. Emanuelovi vráceny na základě rastattské (6. března 1714) a bádenské mírové smlouvy (7. záŕí 1714). ${ }^{61}$ Nepoučen z krizového vývoje v letech 1701-1714 rozpoutal konflikt s Vídní také bavorský kurfiřt Karel Albrecht (1726-1745), který v roce 1741 vztáhl ruce po Čechách (a tedy po čtvrtém kurfiřtském hlasu pro jeho rod) a Horních Rakousích, a roku 1742 se i díky třem wittelsbašským volitelům (Falc, Bavorsko, Kolín nad Rýnem) stal na tři roky římským císařem. ${ }^{62}$ Nebýt Pruska, rozšíŕilo by Bavorsko po roce 1742 počet zemí pod vládou Marie Terezie, jíž by kompenzovalo ztrátu Slezska. Někdejší spojenectví a vzájemně výhodná spolupráce mezi Mnichovem a Vídní z počátku třicetileté války založené roku 1619 byly s odstupem necelých sta let zcela pohřbeny a zapomenuty.

\footnotetext{
56 KÖBLER, G. Historisches Lexikon der Deutschen Länder. Die deutschen Territorien vom Mittelalter bis zur Gegenwart. München: C. H. Beck, 2007, s. 116.

57 Dokumente I/3/2, č. 285, s. 1042-1043.

58 Dokumente I/3/2, č. 348, s. 1242-1252.

59 RALL, H. - HOJER, G. Kurfürst Max Emanuel, der „,Blaue König“. München: Schnell \& Steiner, 1979 , S. 54-55.

60 SPINDLER - KRAUS, c. d., s. 509-510.

61 Tamtéž, s. 513.

62 HLAVAČKA, M. Karel Albrecht. Přiběh druhého zimního krále. Praha: Akropolis, 1997, s. 112 a s. $118-120$.
} 


\section{Závěr}

Přes dalekosáhlé důsledky, které mnichovská dohoda měla, její existence svého času mnoha současníkům, dokonce i jinak dobře informovanému evangelickému historikovi a pobělohorskému exulantovi Pavlovi Skálovi ze Zhoře (1583-1640), unikala. Tento autor ve své Historii církevní mohl v této souvislosti jen fatalisticky konstatovat, že „Bůh všemohoucí, ředitel světa, ráčil jest soudem svým, ač tajným, ale spravedlivým, králi [Fridrichu Falckému] tak mnohé a velikomocné nepřátely, totiž krále hišpánského s celým domem rakouským, papeže, čtyři kurfiřšty svaté říše, kníže bavorské a tak celou Ligu katolickou vzbuditi." 63 Bez pomoci Katolické ligy pod taktovkou Bavorska by česká fáze třicetileté války patrně měla zcela jiný průběh a snad i výsledek. Osudy zemí Koruny české tak zůstaly až do roku 1918 spojeny s habsburskou, od roku 1780 habsbursko-lotrinskou dynastí. Bez uzavření mnichovské dohody v roce 1619 by patrně v současnosti nebyla integrální součástí Svobodného státu Bavorsko také Horní Falc, byt' se dnešní vládní obvod a historická země téhož jména svou výměrou, hranicemi a hlavním městem velmi odlišují. Bez mnichovské dohody z roku 1619 by se politické, náboženské a kulturní osudy Čech, Moravy, Slezska a Horní Falce zcela jistě zásadně vyvíjely jinak.

63 JANÁČEK, J. (ed.). Pavel Skála ze Zhoře. Historie česká. Praha: Svoboda, 1984, s. 290. 